\title{
„Już Napoleon w swoim Kodeksie rozwody upoważnia"1 Kilka uwag w związku z książką Piotra Zbigniewa Pomianowskiego, Rozwód w XIX wieku na centralnych ziemiach polskich. Praktyka stosowania Kodeksu Napoleona w latach 1808-1852
}

W krzywym zwierciadle rozpowszechnionej w dobie Księstwa Warszawskiego satyry przyjęty w tym państwie Kodeks Napoleona uchodził za „dzieło, którego nikt dotąd nie zrozumiał, a które nadto objuczone, w praktyce niedogodne, z sumieniem niezgodne zostało ślepo narzucone na ludzi”. Wprowadzone przez prawo francuskie śluby cywilne prześmiewcza plotka określała jako „tymczasowe umowy zatwierdzone przez kodeks, które wolno każdemu czasu zerwać za ważną przyczyną, to jest zabałamucenia się do innej osoby". Kodeksowi cywilnemu, który wprowadził „wolność rozpusty i cudzołożenia pod innym dachem”, a także kodeksowi procedury cywilnej, „,rodem z piekła” - owemu rozbojowi uprawnionemu „formalnościami jurydycznymi”" przyjrzał się uważnie i zupełnie poważnie Piotr Pomianowski we wskazanej wyżej monografii.

Trzon opracowania tworzą: wprowadzenie, osiem rozdziałów, zakończenie, zestawienia bibliograficzne oraz obszerny aneks. Tytuł monografii skłania do chwili zastanowienia. Zapowiada on mianowicie, że przedmiotem refleksji Autora będzie praktyka stosowania Kodeksu Napoleona w sprawach rozwodowych „na centralnych ziemiach polskich" w latach 1808-1852. Podobnie już w pierwszym zdaniu wstępu Autor koncentruje uwagę czytelnika „na centralnych ziemiach polskich”, na których w początkach XIX wieku wprowadzono „francuskie usta-

\footnotetext{
${ }^{1}$ M. Czacki, Rozprawa o rozwodach, Krzemieniec 1820, s. 1.

2 Warszawa 2018, Wydawnictwo Campidoglio (ss. 449).

${ }^{3}$ H. Bachulska, Księstwo Warszawskie w oświetleniu satyry politycznej z lat 1807-1815, „Przegląd Historyczny” 1924, t. XXIV, s. 28 i n.
} 
wy regulujące prawo cywilne", a więc Kodeks Napoleona, kodeks postępowania cywilnego, a także kodeks handlowy, co, jak podkreśla, stanowiło punkt zwrotny „w naszej historii prawa”. Wspomnianym określeniem operuje Autor także w dalszych partiach tekstu. Z wywodów Autora zawartych we wprowadzeniu wynika jednak, że w zakresie jego zainteresowania znajdzie się Księstwo Warszawskie, Królestwo Polskie oraz Wolne Miasto Kraków. Otóż użycie określenia „centralne ziemie polskie” w kontekście terytoriów zajmowanych przez trzy wspomniane organizmy polityczne budzi pewne wątpliwości. Centralne? W jakim sensie? Zapewne po prostu geograficznym. Ale czy w początkach XIX wieku w wyobrażeniu mieszkańców niedawno rozerwanej Rzeczypospolitej niewielkie Księstwo, znacznie mniejsze Królestwo i maleńka Rzeczpospolita Krakowska były na pewno „ziemiami centralnymi”? A jeśli nawet na rzecz spojrzymy według kryteriów współczesnych, to czy Kraków to rzeczywiście „centralne ziemie polskie”? Z drugiej strony trzeba przyznać, że określenia „centralne ziemie Polski” używano w podobnym kontekście w okresie międzywojennym ${ }^{5}$. Szkopuł w tym, że niełatwo jest zasugerować satysfakcjonujące rozwiązanie, które należycie odda istotę zgłębianego przez Autora zagadnienia, a jednocześnie pozwoli na uniknięcie pewnej niezręczności związanej z koniecznością wymieniania w tytule nazw trzech różnych organizmów politycznych. Poza tym, nie wiadomo dlaczego Autor zdecydował się na wyznaczenie w tytule zrazu szerokich granic chronologicznych i rozciągnięcie ich na cały wiek XIX, aby zaraz potem ograniczyć je do pierwszej połowy tegoż stulecia.

Do refleksji skłaniają też uwagi Autora zawarte we wprowadzeniu, które służą postawieniu problemu badawczego i wskazaniu celu pracy (s. 13 i n.). Autor mówi tam o utrwalonym w literaturze poglądzie głoszącym, ,iż francuskie rozwiązania w zakresie osobowego prawa małżeńskiego w znacznej mierze się u nas nie przyjęły, jako że polskie społeczeństwo było przywiązane do tradycyjnego, katolickiego modelu rodziny, który zakłada nierozerwalność węzła małżeńskiego". Autor stwierdza dalej, że to rozpowszechnione mniemanie z kilku powodów wzbudziło jego wątpliwości. Jednym z nich, jak wyjaśnia, było to, iż „powszechnie znana była praktyka stwierdzania nieważności małżeństw w polskich rodzinach magnackich i ziemiańskich w XVIII wieku. Odnośne zapisy znajdowały się nieraz nawet $\mathrm{w}$ intercyzach. Zatem stosunek polskich elit do nierozerwalności węzła małżeńskiego był co najmniej niejednoznaczny". Nie jest moim zamiarem uprawianie słownej ekwilibrystyki i dzielenie włosa na czworo, ale przyto-

\footnotetext{
${ }^{4}$ Pojawia się tu pewna nieścisłość, bowiem Rzeczpospolita Krakowska istniała do 1846 roku, a po upadku kilkudniowego powstania została wcielona do monarchii austriackiej jako Wielkie Księstwo Krakowskie.

${ }_{5}^{5}$ Kodeksy cywilne obowiazujące na ziemiach centralnych Polski, oprac. E. Muszalski, Warszawa 1936.
} 
czona wypowiedź jest, jak się wydaje, istotna, bowiem wskazuje na pierwotne przesłanki, które kierowały zainteresowaniami Autora i skłoniły go do podjęcia ważnego i trudnego problemu badawczego, dlatego wymaga uwagi. Jest ona także dość kategoryczna, ale zarazem pospieszna, pada w pierwszych akapitach wprowadzenia. Jednym słowem, czytelnik staje od razu w obliczu stanowczego dictum, które stawia go na baczność i mobilizuje do natężenia uwagi, ale także skłania do kontry w formie pytań. Po lekturze przytoczonego fragmentu od razu nieodparcie nasuwa się kwestia czy „powszechnie zn an a [wyróżnienie S.G.] była praktyka stwierdzania nieważności małżeństw w polskich rodzinach magnackich i ziemiańskich", czy praktyka ta była powszechna, bo to zasadnicza różnica. Problem w tym, że ani pierwszego, ani drugiego Autor w uwagach wstępnych nie usiłował, choć to rzecz niebłaha, wykazać, ani nawet tego nie zapowiedział. Poprzestał na wskazaniu w przypisie dwóch opracowań autorstwa Józefa Ignacego Kraszewskiego oraz Tadeusza Czackiego. Gorzej, że z cytowanej wypowiedzi Autora można wysnuć wniosek, że przypadki (przyjmijmy nawet, że, jak zdaje się sugerować Autor, liczne) stwierdzenia nieważności małżeństwa świadczą z punktu o „co najmniej niejednoznacznym” stosunku polskich elit do problemu jego nierozerwalności, z czym trudno byłoby się zgodzić. Sądzę, że Autor nie pokazał niczego, co uzasadniałoby takie twierdzenie. Częściowe wyjaśnienie wątpliwości co do prezentowanego przez niego stanowiska przynoszą końcowe fragmenty rozdziału pierwszego (s. 58 i n.), gdzie Autor przytacza źródła oraz cytuje kilka opracowań naukowych, które ilustrują bądź traktują o praktyce nadużywania (a to już co innego) procesów o stwierdzenie nieważności małżeństwa. Znów powraca tam motyw intercyz. Autor powtarza, że w Polsce „częste było zawieranie postanowień co do stwierdzenia nieważności małżeństwa już w intercyzach" i przywołuje w przypisie ponownie te same publikacje Kraszewskiego i Czackiego (z dodaniem zdania cytatu o „poczwarnych transakcjach przedślubnych" $z$ tego ostatniego), tym razem uzupełniając je o dwie prace Anny Penkały, której badania, jak przyznaje, ,nie potwierdzają takich praktyk”. Zanim pójdziemy dalej, należy wskazać na pewną nieścisłość. Otóż Piotr Pomianowski cytuje wypowiedź Czackiego, która brzmi: „Zaczęły być znane poczwarne transakcje przedślubne, w których przypadek rozwodu był ostrzeżony dla utrzymania

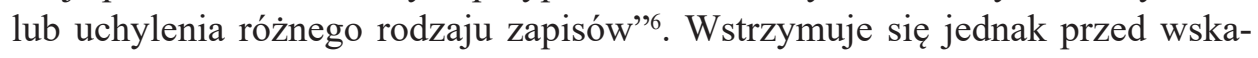
zaniem czytelnikowi, że składa się na nią jeszcze jedno zdanie, wyodrębnione wraz z tamtym w osobnym akapicie: „Rozumiem, że takowe umowy jako turpe

6 T. Czacki, O litewskich i polskich prawach, t. II, Warszawa 1801 (reprint Warszawa 1987), s. 31 (w przypisie). Piotr Pomianowski cytuje według wydania z 1844 roku, o czym będzie jeszcze mowa. 
pactum są nieważne, a rodzice lub strony zawierające takie umowy powinny być surowo karane".

Przechodząc do porządku nad tymi kwestiami należy stwierdzić, że czytelnik pozostaje z uczuciem pewnego niedosytu i zachodzi w głowę, cóż takiego zawierały owe potencjalnie groźne dla małżeńskiego węzła intercyzy? Z narracji Autora nie można się wiele na ten temat dowiedzieć. Powoływany przez Piotra Pomianowskiego Kraszewski, malując przygnębiający obraz obyczajowości, a ściślej „Życie rodzin od czasów Augusta II”, rzucił właściwie jedno zdanie: „Rozwody były przewidywane już w intercyzach ślubnych", które przecież różnie może być rozumiane ${ }^{7}$. Zapewne należałoby ostrożnie przyjąć, że umowy takie były pojemne i stanowiąc przejaw zapobiegliwości stron, niejednokrotnie drobiazgowo regulowały poszczególne aspekty stosunków między przyszłymi małżonkami, w tym także i tę delikatną kwestię, która wiąże się z konsekwencjami ewentualnego „rozwodu”. Tyle tylko, że ta przenikliwość i dokładność mogła wynikać także z przyczyny bardzo podstawowej i prozaicznej, której Piotr Pomianowski chyba nie wziął pod uwagę, a mianowicie z niedostatków, luk lub trudnych albo zgoła niemożliwych do przezwyciężenia zawiłości obowiązującego prawa, a - co za tym idzie - pewnego ryzyka znalezienia się w przyszłości w podwójnie kłopotliwej sytuacji. To właśnie dlatego Ignacy Daniłowicz pisał w swej pracy poświęconej porównaniu Kodeksu Napoleona z prawami polskimi i litewskimi, której nawiasem mówiąc Autor nie wykorzystał, że „praktyka musiała polegać całkowicie na intercyzach przedślubnych"».

Piotr Pomianowski stwierdził ponadto, że

zobowiązanie do wspólnego dążenia do stwierdzenia nieważności małżeństwa niekiedy obwarowywano karami pieniężnymi. Postanowienia tego rodzaju bywały aprobowane przez sądy kościelne, które nakazywały wypłatę kar (s. 59).

Pogląd ten wsparł odesłaniem do książki Stefana Biskupskiego, a ściślej do cytowanego w niej wyjątku z dokumentu wydanego przez papieża Benedykta $\mathrm{XIV}^{9}$. Zaznaczmy nawiasem, że Biskupski twierdził, że

„Specjalnością” niejako górnych warstw społeczeństwa polskiego w sposobach rozbijania małżeństw były układy, zawierane między stronami, że związek ich będzie w przyszłości unieważniony,

7 J.I. Kraszewski, Polska w czasie trzech rozbiorów 1772-1799. Studia do historii ducha i obyczaju, t. I, 1772-1787, Oświęcim 2015, s. 128 i n. Piotr Pomianowski cytuje według wydania z 1902 roku.

${ }^{8}$ I. Daniłowicz, Kodeks Napoleona w porównaniu z prawami polskimi i litewskimi, wyd. A. Kraushar, Warszawa 1905, s. 51.

${ }^{9}$ S. Biskupski, Obrońca węzła w kanonicznym procesie matżeńskim, Łódź 1937, s. 83, 84, przypis 31 . 
natomiast nie podał ani jednego przykładu takiej umowy. Powtórzył tylko za Kraszewskim, że rozwody przewidywano już w intercyzach przedślubnych i stwierdził, że:

zmowy takie obwarowywano karami pieniężnymi na wypadek, gdyby jedna ze stron chciała od nich później odstąpić i bronić małżeńskiego związku. Lecz najdziwniejsze w tym jest to, że kary takie uznawane były przez sądy kościelne, które też nakazywały wypłatę kary umownej w całości...

Biskupski zwrócił dalej uwagę, że Benedykt XIV z goryczą pisał o tych praktykach, potępił je, a wspomniane „,zmowy pozbawił wszelkiego prawnego znaczenia pod grozą ekskomuniki latae sententiae, zastrzeżonej Stolicy Apostolskiej”. Wróćmy jednak do wspomnianego wyżej wyjątku z dokumentu papieskiego. Ośmielę się podnieść, że interpretacja tekstu dokonana przez Piotra Pomianowskiego może być wątpliwa ${ }^{10}$. Czy rzeczywiście wynika z niego zobowiązanie małżonków „do w s póln e g o [wyróżnienie S.G.] dążenia do stwierdzenia nieważności małżeństwa"? Owszem, małżonkowie życzą sobie z jakichś przyczyn doprowadzenia do „zerwania małżeństwa”, są na to oboje zdecydowani (pytanie, co w sytuacji, gdy jedna ze stron zmieni zdanie, choćby w czasie trwania procesu), ale ich zobowiązanie dotyczy przecież czegoś innego. Umawiają się mianowicie, że karę na rzecz kontrahenta zapłaci ta strona, która już „,po ogłoszeniu przez sędziego kościelnego wyroku o nieważności małżeństwa” będzie się chciała odwoływać wbrew wyraźnym intencjom drugiej strony, która z orzeczeniem się zgadza. Wydaje się, że to jednak różnica w stosunku do, jak mówi Autor, ,zobowiązania do w s póln e g o [wyróżnienie S.G.] dążenia do stwierdzenia nieważności małżeństwa".

Co się zaś tyczy przytoczonego przez Piotra Pomianowskiego świadectwa Nathaniela Williama Wraxalla (s. 61), że rzekomo w Rzeczypospolitej ,jest łatwość rozwodów i ich powszechność” oraz że „w każdym innym kraju zwyczaje tak odrażające $\mathrm{z}$ punktu widzenia naczelnych zasad moralności byłyby niezwłocznie ukrócone. W Polsce jednak zarówno przepisy prawa, jak więzy honoru i przyzwoitości są bez znaczenia"11, to jeśli dwa pierwsze cytowane zdania jego relacji są tak samo prawdziwe jak trzecie, to $\mathrm{z}$ całą pewnością nie należy im wierzyć. Wraxall, mówiąc o upadku obyczajów i rozwodach, które były, jak oceniał, ,jedną z naturalnych konsekwencji tego stanu rzeczy”, powtarzał wielokrotnie: „powszechne rozprężenie obyczajów wśród sfer wyższych”; ,jeśli taki jest stan

${ }^{10}$ Nawiasem mówiąc Piotr Pomianowski nie wspomniał, kto dokonał przekładu fragmentu na język polski. Biskupski podał tekst w języku łacińskim, Autor analizowanej monografii po łacinie i po polsku.

${ }^{11}$ N.W. Wraxall, Wspomnienia z Polski, [w:] Polska Stanisławowska w oczach cudzoziemców, t. I, opracował i wstępem opatrzył W. Zawadzki, Wrocław 1963, s. 539, 540. 
warstw wyższych”; ,po tak odrażającym obrazie występków warstw wyższych” ${ }^{12}$, co skłania raczej do odniesienia jego uwag tylko do pewnych elitarnych kręgów. Ciekawe też, jaki jest stosunek rzekomej „łatwości rozwodów i ich powszechności” dostrzeżonej przez Anglika w Rzeczypospolitej do liczby „rozwodów” między katolikami wymienionej przez Piotra Pomianowskiego za Czackim. Rzecz jest warta rozważenia.

Czacki twierdził, że „rozwody” w Polsce jeszcze „od 1720 do 1733 roku były w zbyt małej liczbie, i jeszcze rozwiedzeni cechą hańby przez opinię publiczną byli naznaczeni" ${ }^{13}$. Piotr Pomianowski pominął ten szczegół. Wskazał natomiast, że

Sytuacja panująca w Polsce należała do głównych przyczyn reformy procesu kanonicznego w sprawach małżeńskich, przeprowadzonej przez Benedykta XIV bullą Dei miseratione wydaną w 1741 roku (s. 60).

W przypisie Autor wspomniał (s. 60, przypis 133), że w piśmiennictwie znaleźć można pogląd odmienny, a w konsekwencji, ujmując rzecz nieco inaczej, stwierdził tamże:

Nie przesądzając sporu, czy sytuacja w Polsce była głównym powodem wydania bulli, czy tylko jednym z wielu, przypomnijmy jeszcze tylko, że Benedykt XIV wystosował do polskiego episkopatu aż cztery dokumenty dotyczące nadużyć w kanonicznych procesach małżeńskich.

Kontynuował dalej Autor swą myśl w tekście głównym (s. 60 i n.), pisząc:

Reforma postępowania zapewne nie przyniosła jednak oczekiwanego skutku. Według Tadeusza Czackiego za panowania Stanisława Augusta Poniatowskiego orzeczono w Polsce 451 „rozwodów” między katolikami, z czego konsystorz warszawski stwierdził nieważność 178 małżeństw.

W przypisie podał jeszcze jednozdaniowy cytat z Czackiego traktujący o komisjach, których dekrety nie były oblatowane i o łącznej liczbie około 500 katolickich „rozwodów” w Polsce. Wszystko to zdaje się mówić czytelnikowi, że w przedrozbiorowej Rzeczpospolitej rozwodzono się często.

Tymczasem wydaje się, że Autor w niemałym stopniu zmienił sens wypowiedzi Czackiego. Fragment, na którym Piotr Pomianowski się skoncentrował, brzmi następująco:

Za ostatniego panowania jeden konsystorz warszawski mający nad stolicą i kilku dekanatami tylko władzę dał rozwodów 178. A w ogóle w Polszcze było za tego panowania rozwodów wiadomych między katolikami 451. Dodając liczbę tych rozwodów, które w komisjach z Rzymu

\footnotetext{
12 Ibidem, s. 537, 538, 540.

13 T. Czacki, O litewskich, s. 31 (w przypisie).
} 
wyznaczonych były skończone, a których dekreta nie są oblatowane, można śmiało 500 katolickich rozwodów ustanowić. Więcej jak trzecia część rozwodów była w stolicy, a odtrąciwszy dysydentów, przyjeżdżających, żołnierzy i biorąc średnią proporcję zaludnienia Warszawy przez trzydzieści lat pomnażanej zapewne katolików nie było obojej płci jak 80 lub 90000 ludzi. A cały kraj do pierwszego podziału katolików mógł liczyć 6500 000, a od 1775, 4800000 lub 5 milionów ludzi. Tak to stolica z kilku dekanatami będąca w pierwszej epoce siedemdziesiąt piątą, potem pięćdziesiąt piątą częścią katolików więcej jak trzecią część rozwodów wydała, a jeśli przyłączymy delegacje w Warszawie odprawiane do sądzenia rozwodów z innych diecezji, zapewne niemal dwie trzecie części rozwodów wydanych było w stolicy. Jedna jeszcze uwaga warta jest zastanowienia, że w dwóch latach, kiedy Polak widzi epokę publicznego frymarku Rzeczypospolitej, kiedy regestr liczy niecnych czynów publicznych, i prywatnych, wtenczas w latach 1775, i 1793 najwięcej było rozwodów w stolicy, jak akta świadczą. Oto są podobno dowody, że rozwody są miane za potrzebę miast, ale nie są potrzebą kraju.

Do czego zmierzał wywód Czackiego okraszony statystycznymi danymi? Do wniosku, że „rozwody są miane za potrzebę miast, ale nie są potrzebą kraju”. Powtórzmy: „nie są potrzebą kraju”. Zwróćmy uwagę, że Czacki zapowiadał wcześniej wyraźnie, i to w tym samym rozbudowanym przypisie, co będzie osią jego refleksji:

Weźmy regestr rozwodów jakiegokolwiek kraju, przekonamy się łatwo, że najwięcej w miastach jest tych rozłączeń. Zwróćmy teraz uwagę na Polskę, i na tę proporcję, jaka jest między rozwodami na wsiach i w miastach ${ }^{14}$.

Jeśli tak, to wywód Czackiego każe raczej wątpić w tezę o domniemanej powszechności rozwodów, a nie ją uzasadniać. O tym, że taki właśnie był sens wypowiedzi Czackiego świadczy jeszcze i to, że za wskazaniem, iż rozwody „nie są potrzebą kraju", zaraz w następnym zdaniu, mówił on:

Za panowania ostatnich królów od 1733 do 1786 Smogorzewski, metropolita ruski nie znalazł rozwodów w tak wielkiej ludności obrządku ruskiego jak jedenaście.

Piotr Pomianowski również odnosi się do wzmianki o danych Smogorzewskiego, ale czyni to w nieco innym kontekście, pisząc:

Należy przy tym zaznaczyć, że wśród innowierców rozwód nie był bynajmniej zjawiskiem powszechnym. Przykładowo: unicki metropolita kijowski Jason Junosza Smogorzewski miał naliczyć wśród współwyznawców w latach 1733-1786 zaledwie 11 rozwodów (s. 58).

Otóż Czackiemu, jak się wydaje, nie chodziło tu przede wszystkim o uchwycenie różnic według kryterium: liczba rozwodów a wyznanie (choć rzeczywiście wzmiankuje nieco dalej o protestantach i mówi o „zbyt wielkiej” w stosunku do

14 Ibidem, s. 31 (w przypisie). 
populacji liczbie rozwodów), tylko o wskazanie, że w mieście (właściwie w Warszawie) rozwody idą w dziesiątki, ale jest to swego rodzaju ewenement, stan sztuczny, a przy tym zjawisko falowe, zależne nawet od bieżących wydarzeń politycznych, ale absolutnie nie jest ono specyfiką prowincji. Dlatego pewnie podkreślał: „w tak wielkiej ludności”.

Powróćmy jeszcze na chwilę do owych 500 rozwodów szacowanych przez Czackiego. Zupełnie nawiasem wspomnijmy, że cyfry te, a więc 451 „rozwodów” między katolikami za ostatniego króla, z których 178 miał orzec konsystorz warszawski, plus nieznana bliżej „liczba tych rozwodów, które w komisjach z Rzymu wyznaczonych były skończone, a których dekreta nie są oblatowane”, dające w przybliżeniu owe „500 katolickich rozwodów”, były podawane za Czackim nawet w wykładach uniwersyteckich jeszcze w końcu lat dwudziestych XIX stulecia ${ }^{15}$. A więc czy te $500 \mathrm{w}$ skali kraju w czasach Poniatowskiego, tj. przez 31 lat - innymi słowy - 16 rocznie, to już wspomniana przez Anglika „powszechność”? „Epidemia”? Tak właśnie zdaje się sugerować autor piszący na początku XX stulecia, którego przywołuje Piotr Pomianowski (s. 41, przypis 44). A może te przybliżone pięć setek to jeszcze tylko stan - jak powiadał biskup Wojciech Skarszewski, którego cytuje Autor - „,zagęszczonych nazbyt rozwodów”. Zresztą ile z nich zakończyło się stwierdzeniem nieważności, używając określenia cytowanego przez Piotra Pomianowskiego kardynalskiego listu, „z motywacji i przyczyn bardzo różnych od tych, przewidzianych przez święte kanony oraz za sprawą pieniądza, który często wpływa na te decyzje" - co wskazywałoby rzeczywiście na lżejszy stosunek szlachty do sakramentalnego węzła, a ile lege artis na skutek przyczyn najzupełniej zgodnych z prawem? Czy są choć przybliżone, wiarygodne, spełniające wymogi współczesnej nauki wyniki badań dotyczące tej materii? Autor ocenianej monografii ich nie przedstawił. Wspomniany już wyżej Stefan Biskupski, który pozostając pod wyraźnym wrażeniem upomnień słanych przez Stolicę Apostolską do Kościoła polskiego oraz przekazów kronikarskich i zapatrywań Czackiego w dość czarnych barwach malował obraz moralności staropolskiej w XVIII wieku' ${ }^{16}$, pokusił się o weryfikację szacunków tego ostatniego dotyczących liczby rozwodów. Piotr Pomianowski o tym nie wspomniał. Tymczasem Biskupski pisał:

W archiwum Metropolitalnej Kurii Warszawskiej usiłowaliśmy sprawdzić liczby wyroków podanych przez Czackiego i ogłaszających nieważność małżeństwa. Nie udało się to w całej pełni, ponieważ brak jest $\mathrm{w}$ archiwum wszystkich woluminów sądowych z tego czasu. W znale-

${ }^{15}$ Zob. Prawo polsko-litewskie, k. 205-206. Wydaje się, że jest to tekst wykładu Ignacego Daniłowicza. Rkps, Lwowska Naukowa Biblioteka im. W. Stefanyka NAN Ukrainy. Oddział rękopisów. Zespół (fond) 5. Rękopisy Biblioteki Zakładu Narodowego im. Ossolińskich, 5355/I, http:// bazy.oss.wroc.pl/kzc/wyniki_pl.php?RL-001087.

16 S. Biskupski, Obrońca węzła, s. 73 i n. 
zionych natomiast woluminach 10, 45, 60, 61, 62, 63, 64, 65, 66, 67, 68, 69, 70 zarejestrowano 167 spraw o nieważność. Z tych trzydzieści kilka zakończono wyrokiem orzekającym, iż ma1żeństwo było zawarte nieważnie; reszta - to sprawy niezakończone ${ }^{17}$.

Wyjaśnienia te oczywiście niewiele mówią nam o proporcjach masy odnalezionego materiału do tego, który się nie zachował, a także o tym, z jakiego dokładnie okresu badane akta pochodziły. Czy rzeczywiście tylko z czasów Stanisława Augusta Poniatowskiego, czy może także wcześniejszych? Biskupski nic też bliżej nie powiedział o metodzie swych dociekań. Trudno tu więc o wnioski. Biskupski ich nie postawił. Wydaje się jednak, że badacz nie znalazł niczego, co skłoniłoby go do stwierdzenia, że Czacki radykalnie się mylił, bo pewnie na okoliczność tę nie omieszkałby wskazać.

Oczywiście nie ma wątpliwości co do tego, że nadużyć się dopuszczano i w wieku XVIII, i później. Przecież Czacki też zastrzegał:

Dowiodłem nadużycia swobody rozwodów, okazałem ich okropność; lecz nie zaprzeczam, aby nie były przyczyny do ogłoszenia małżeństwo za niebyłe, a rozerwanie będącego związku małżeńskiego, w wyznaniu protestantów powinno (ile mi się zdaje) być nieoddzielnym od kary cywilnej na winnego małżonka, a tak rząd miałby baczność nad obyczajami, w których zepsuciu wylęgają się rozwody. Wreszcie u katolików kiedy rząd nie rzucił oko na tę ważną część postępowań konsystorskiej władzy, kiedy każda rozwódka rozumiała się być wolną od męża, a panią swojej woli, kiedy zgasła moc opinii publicznej o nieprawnych rozwodach, musiało te nieszczęście się powiększać, i prowincje zarażać ${ }^{18}$.

\section{W ostrych słowach o nadużyciach mówił Ignacy Daniłowicz:}

Prawa nasze nic o rozwodach nie uczą, lecz do kanonów odsyłają. Te, pozwoliwszy separacji małżonkom, żyć dla srogości nie mogącym, zakazały rozwodów. Czternaście atoli przyczyn nullitatis tak zręcznie podciągać wyuczyli się kanoniczni prawnicy, że każde małżeństwo, byle się dobrze opłaciło, niezawodnie starganie związków otrzyma, i ledwie może jeden rozwód, z kilkunastu corocznych, dla prawdziwej dany był przyczyny, bo reszta, opłaciwszy świadków, adwokatów i sekretarza, podstępnie sąd oszukała. Dowodem tego być może, iż żaden w Litwie rozwód otrzymanym nie był, któryby 100 najmniej, a czasem i 1000 dukatów nie kosztował, gdy przecież dla przyczyn prawnych darmo otrzymywanym być powinien, wedle nauki Zbawcy i praw naszych.

\section{Zaraz dalej badacz dodawał:}

Ta więc istotna między francuskimi i naszymi prawami zachodzi różnica, że tam zarówno bogaty i ubogi, Żyd, luter lub katolik, nie mogący żyć w małżeństwie, rozwiązanie jego otrzyma, gdy u nas dobrodziejstwo takowe samym bogaczom zostawione, a prawo patrzeć musi obojętnie na też same przyczyny, kmiotka z żoną pożycie nieznośnym czyniące, owszem,

\footnotetext{
${ }^{17}$ Ibidem, s. 75, przypis 5.

18 T. Czacki, O litewskich, s. 32 (w przypisie).
} 
rygor jego sięgnąć nie może tych nawet małżeństw, które rzeczywiście z pogwałceniem jego zawarte zostały. Jakoż nikt nie zdoła okazać przykładu, by choć jeden kmiotek rozwiedzionym zosta ${ }^{19}$.

Nieco wcześniej zwracał zresztą uwagę:

Nie wolno zatem we Francji, tak jak u nas, opatrzywszy się nieraz po 20 latach pożycia zrywać małżeństwa dla przymuszenia lub błędu ${ }^{20}$.

Skoro jesteśmy przy opiniach Daniłowicza, to na marginesie warto wskazać na jeszcze jedną ciekawą okoliczność. Szlachta litewska miała okazję zastanowić się nad problemem nierozerwalności małżeństwa także w świetle bardzo długo na Litwie obowiązującego prawa statutowego. Otóż art. 5 z rozdz. XI Statutu z 1588 roku stanowił, że żona wywołańca „ma być rozumiana jako wdowa, dzieci jego sierotami, a dom jego pusty"21. Jak to stanowisko prawa litewskiego można było pogodzić z prawem kanonicznym Daniłowicz nie był „W stanie osądzić”22.

W ramach wtrącenia zwrócę uwagę na jeszcze jeden szczegół. Otóż w 1830 roku znany prawnik i historyk, Józef Jaroszewicz, wykładowca prawa rzymskiego i krajowego w Krzemieńcu, a potem w Wilnie, w liście do Joachima Lelewela ${ }^{23}$ wspominał krótko o wizycie, którą złożył mu Aleksander Mickiewicz, także nauczyciel prawa rzymskiego i krajowego w Wołyńskich Atenach (potem rzymskiego na uniwersytetach w Charkowie i Kijowie). W trakcie spotkania Mickiewicz wspomniał Jaroszewiczowi o jakiejś rozmowie, którą miał z Lelewelem na temat rozwodów. $Z$ tenoru listu można wnosić, że na tym tle rozpoczęła się wymiana poglądów także i między Mickiewiczem a Jaroszewiczem w bezpośredniej rozmowie. Otóż ten ostatni następująco charakteryzował poglądy swego interlokutora:

Wielki jest stronnik kościelnej surowości. Kiedym mu wspomniał o krzyczących nadużyciach naszych konsystorzów, nie odstępując od swego zdania, życzył tylko żeby tym nadużyciom zapobieżono!!

Wracając do rzeczy, zapytuję raz jeszcze, czy materia ta została przez naukę należycie rozpoznana i czy istnieją jakieś, nawet szacunkowe dane, będące wynikiem metodycznych badań? Jeśli nie, to wydaje mi się, że rzeczywiście „rypisie).

19 I. Daniłowicz, Kodeks Napoleona, s. 124 i n. Zob. też T. Czacki, O litewskich, s. 31 (w przy-

${ }^{20}$ I. Daniłowicz, Kodeks Napoleona, s. 112.

${ }^{21}$ Statut Wielkiego Księstwa Litewskiego, Wilno 1786.

22 I. Daniłowicz, Kodeks Napoleona, s. 113 i n.

${ }^{23}$ List opatrzony tylko datą roczną, zapewne $z$ Wilna. Jest to kopia zachowana w papierach A. Janulaitisa. Rkps, Lietuvos mokslų akademijos Vrublevskių biblioteka, Rankraščiu skyrius, f. 267-1340, k. 594-613 (cytowany fragment na k. 613). 
zykuje stwierdzenie” autor, gdy mówi, że „wprowadzenie świeckiego rozwodu nie było - przynajmniej dla wyższych warstw polskiego społeczeństwa - żadną rewolucją" (s. 62). Ryzykuje tym bardziej, gdy w zakończeniu sam przyznaje, że:

Skala fenomenu w państwie polsko-litewskim, jak również bezpośrednio po rozbiorach nie jest co prawda znana, ale nie można mieć wątpliwości, że w pojęciu niemałej części katolickiej szlachty ziemiańskiej małżeństwo nie miało bynajmniej nierozerwalnego charakteru (s. 288),

a zaraz dalej mówi:

Zestawienie skali zjawiska w czasach staropolskich - niedająca się wprawdzie precyzyjnie określić, ale bez wątpienia znaczna liczba „rozwodów” kościelnych - i w okresie napoleońskim mogłoby sugerować, że w sumie niewiele się zmieniło w społecznym podejściu do rozwodu (s. 295-296).

Myśl biegnie wtedy do racji arcybiskupa Ignacego Raczyńskiego, który w liście do ministra Feliksa Łubieńskiego wyłuszczał:

Minister mówi, że po wprowadzeniu prawa cywilnego o ślubach i rozwodach, odtąd rozwody tak łatwo nie pójdą. Doświadczenie inaczej przekonywa. W przeciągu sześciu lat więcej było rozwodów cywilnych, niźli w przeciągu lat sześćdziesięciu rozwodów religijnych. Przypominamy tu panu ministrowi, że w miesiącu kwietniu roku 1809 było zalecenie dane przez niektórych prefektów, wywiadywania się sekretnie o małżeństwach źle, niezgodnie żyjących, a to dla ułatwienia im rozwodów. Czynili to dla przysłużenia się stronom, pragnącym rozwodów ${ }^{24}$.

Wracając do treści ujętych we wprowadzeniu, trzeba natomiast stwierdzić, że na całkowitą aprobatę zasługuje zadeklarowana przez Piotra Pomianowskiego intencja odsłonięcia fragmentu ,praktyki stosowania prawa cywilnego” (s. 16), tym bardziej, że w zakresie postępowań rozwodowych w Księstwie Warszawskim i Królestwie Kongresowym, jak on sam podkreśla, pozostawała ona dotychczas poza ,jakimkolwiek zainteresowaniem badaczy”, jeśli nie liczyć kilku szkiców opublikowanych przez tegoż autora w ciągu ostatnich lat (zob. s. 17, przypis 13). Docenić należy również ambitne wysiłki Piotra Pomianowskiego zmierzające do zgromadzenia odpowiedniej podstawy źródłowej dla prowadzonych badań, zwłaszcza w postaci materiałów archiwalnych. Niewątpliwie samo dotarcie do nich, nie mówiąc o analizie i opracowaniu, kosztowało dużo czasu, fatygi i pracy. Autor sięgnął bowiem do zasobów aż kilkunastu archiwów państwowych oraz kilku kościelnych. Zaczerpnął ze zbiorów Archiwum Głównego Akt Dawnych w Warszawie, Archiwum Narodowego w Krakowie oraz Archiwów Państwowych w: Białymstoku (oddział w Łomży), Bydgoszczy, Katowicach, Kielcach, Lublinie, Łodzi, Piotrkowie Trybunalskim, Płocku, Poznaniu, Radomiu, Suwałkach,

${ }^{24}$ Cyt. za: Wspomnienia lat minionych Eu-go Heleniusza, t. I, Kraków 1876, s. 89 i n. 
Toruniu i Warszawie. Oprócz tego wydobył materiały z Archiwum Archidiecezjalnego w Gnieźnie, Archiwum Archidiecezjalnego w Poznaniu, Archiwów Diecezjalnych w Łomży, Siedlcach i we Włocławku, Archiwum Kurii Metropolitalnej w Krakowie, a nawet jednego z archiwów parafialnych (Grajewo). W efekcie udało się zdobyć i spożytkować wyroki właściwych dla orzekania w sprawach rozwodowych trybunałów cywilnych pierwszej instancji (akta sądów odwoławczych z doby istnienia Księstwa i Królestwa nie zachowały się) funkcjonujących w Bydgoszczy, Kaliszu, Krakowie i Warszawie. Obok dokumentacji sądowej podstawowy zrąb materiału źródłowego stanowią akta stanu cywilnego w postaci odpowiednich ksiąg oraz załączników do akt stanu cywilnego (tzw. allegatów czy annexów). Oczywiście nie wszystkie wytypowane do badań zespoły archiwalne zostały objęte pełną kwerendą. Autor zmuszony był ograniczyć się niekiedy, i to z różnych względów, tylko do badania sondażowego. Nie jest do końca jasne, w jakim stopniu zdołał spenetrować ,względnie kompletne” akta trybunału kaliskiego, które zachowały się w ogromnej masie ponad 1200 tomów. Na pochwałę zasługuje staranność, z jaką Autor podszedł do problemu właściwego doboru tekstów normatywnych, na czele ze źródłem bazowym, a więc Kodeksem Napoleona. Piotr Pomianowski zdecydował o przyjęciu za „tekst wyjściowy” francuskiego oryginału, który stał się „podstawą" jego analiz oraz o pomocniczym korzystaniu z tłumaczeń. Tę samą zasadę przyjął dla kodeksu procedury cywilnej z 1806 roku oraz pruskiego Landrechtu. Sięgnął także Autor do dziewiętnastowiecznych komentarzy.

Rozdział I monografii zatytułowany Sakralizacja i laicyzacja prawa małżeńskiego w Europie (s. 29-69) ma jeszcze charakter wstępny w stosunku do węzłowej problematyki, którą zajął się Autor dopiero w kolejnych częściach pracy. Dziwi nieco maniera Autora, który zdradza czytelnikowi swe intencje na raty. Oto kreśląc plan rozdziału, mówi najpierw, że rezygnuje z przedstawienia unormowań odnoszących się do instytucji małżeństwa „w prawie wewnętrznym wszystkich wspólnot religijnych odgrywających istotną rolę w dawnej Rzeczpospolitej" i zapowiada, że skoncentruje się na „uregulowaniu małżeństwa i rozwodu w Kodeksie Napoleona oraz poprzedzającym je ustawodawstwie rewolucyjnym, w którym należy upatrywać źródeł inspiracji twórców Code civil”, czyniąc jednocześnie z Landrechtu i ustawodawstwa austriackiego pewne punkty odniesienia (s. 29). Dopiero dalej, po uwagach na temat małżeństwa i rozwodu w świetle Pisma Świętego, dodaje, że zamierza także przyjrzeć się „,ewolucji osobowego prawa małżeńskiego w Rzeczypospolitej Obojga Narodów” (s. 34). Pomijając fakt, że wbrew zapowiedzi Autor właściwie nic nie mówi w rozdziale pierwszym o Kodeksie Napoleona w anonsowanym wcześniej kontekście, to przyjęte przez niego założenia są, jak się wydaje, słuszne. Zwłaszcza rzut oka na przemiany prawa francuskiego, pruskiego i austriackiego, które stopniowo zaczynały obowiązywać na znacznej 
części terytoriów rozszarpywanej Rzeczypospolitej, jest z pewnością pożyteczny i - jak chciał Autor - sprawia, że „późniejsze wywody dotyczące stosowania Kodeksu Napoleona w Polsce nie zawisły w próżni”.

Tytuł jednego z podrozdziałów w rozdziale I: Małzeństwo i rozwód w Starym $i$ Nowym Testamencie jest sformułowany wyraźnie na wyrost w stosunku do zawartych w nim treści. Wrażenia tego nie thumi nawet uczynione przez Autora zastrzeżenie, że cały rozdział, który go mieści, ma być jedynie pobieżnym szkicem problematyki. Zarys może w zupełności wystarczyć, o ile w jego świetle czytelnik jasno ujrzy kontury problemu i ścieżkę do ewentualnych dalszych poszukiwań wytyczoną przez Autora rozważnie wskazaną literaturą. Wydaje się, że w tym przypadku obu tych rzeczy zabrakło. O nauczaniu Ojców Kościoła na temat nierozerwalności małżeństwa pisał ostatnio sporo Ginter Dzierżon („Ius Matrimoniale" 2015, nr 1, nr 2; 2016, nr 3). Na pewno przydałby się tekst Wojciecha Góralskiego, Problem rozwodu i powtórnego matżeństwa w pierwotnym Kościele do Soboru Nicejskiego włacznie („Ius Matrimoniale” 2016, nr 4, s. 5-42). Czy zresztą owo dążenie do skrótu i zwięzłości nie sprowadziło Autora na manowce, gdy stwierdził (s. 32), że „w późnym średniowieczu małżeństwo na Zachodzie zaliczono w poczet sakramentów"? W pierwszej chwili, niemal bezwiednie, przypominają się słowa Daniłowicza o francuskich uczonych, którzy niejednokrotnie

roztrząsali tę kwestię, czyli istotnie był potrzebnym zbieg władzy dwoistej do ważności i utwierdzenia małżeństwa, czyli też dość było akt ten cywilnym tylko zostawić? W ślepym zapale rzekli, że otworzone księgi dawnego i nowego przymierza nigdzie nie ukażą podwyższenia do Sakramentu małżeństwa, które dopiero Innocenty III papież do tej podniósł godności, a Zbór Trydencki utwierdził².

Potem pamięć wydobywa jeszcze kilka nazwisk i prac, które skłaniałyby do ostrożności w stawianiu w ten sposób wspomnianej kwestii.

Trzeba przyznać, że dość osobliwa jest uwaga Autora, która pada w jednym z ostatnich akapitów I rozdziału. Po wzmiance na temat idei nowelizacji Kodeksu Napoleona, które pojawiły się w dobie istnienia Księstwa Warszawskiego oraz niemożliwości ich zrealizowania także ze względu na „nastawienie cesarza do kodeksu jego imienia", Autor stwierdził, że

poważnie więc o zniesieniu rozwodów można było myśleć dopiero po tym, jak Aleksander I przejął kontrolę nad Księstwem Warszawskim. Problemowi temu wiele uwagi poświęcono w czasie obrad powołanego przez cara Komitetu Cywilnego Reformy w latach 1814-1815. Już ukaz powołujący wspomniany komitet w art. 7 mówił o konieczności przywrócenia klerowi utraconej przezeń pozycji, co oznaczało między innymi zapowiedź zmian w organizacji akt stanu cywilnego (s. 66).

${ }^{25}$ I. Daniłowicz, Kodeks Napoleona, s. 107 i n. 
Owszem, po zajęciu Księstwa przez Rosjan rozważano zniesienie rozwodów, tyle że wraz z całym Kodeksem Napoleona i z francuską procedurą w dodatku. Szymon Askenazy przed ponad stu laty następująco zaczął krótki szkic dotyczący tego problemu:

Kodeks Napoleona w dobie tworzenia Królestwa, 1813-1815, był narażony na groźbę zniesienia, bardzo poważną,

aby dodać zaraz dalej, że kodeks miał w chwili upadku Księstwa „opozycję silną a różnorodną" ${ }^{26}$. Trzeba przypomnieć, że już w memoriale złożonym Aleksandrowi I w marcu 1814 roku w Chaumont książę Adam Jerzy Czartoryski doradzał jak najszybsze zniesienie Kodeksu Napoleona oraz francuskiej procedury cywilnej i ich tymczasowe zastąpienie prawem polskim, Statutem litewskim oraz formami sądowymi istniejącymi przed wprowadzeniem procedury francuskiej ${ }^{27}$. Idea ta była zresztą mocno krytykowana przez środowisko prawnicze Księstwa. Sugestie Czartoryskiego zostały jednak uwzględnione i stosowne dyspozycje zawarto w 2 artykule carskiego aktu wydanego w Paryżu 19 maja 1814 roku, który określał zadania Komitetu Cywilnego Reformy. Zakładano, że stworzone $\mathrm{w}$ ten sposób prowizorium przetrwa do czasu przygotowania nowych kodeksów: karnego, cywilnego, postępowania sądowego oraz stworzenia nowej organizacji sądów ${ }^{28}$. Już podczas drugiej sesji Komitetu Reformy, która odbyła się 7 lipca 1814 roku, prezydujący na posiedzeniu Mikołaj Nowosilcow podał „swoje myśli względem podziału prac komitetu na sekcje” i uznawszy, że Komitet i tak nie zdoła opracować wszystkich kwestii przed spodziewanym przyjazdem cara do Warszawy, zaproponował, aby zając się wybranymi zagadnieniami, do których zaliczył i to, że „wypadałoby wyrzec o zniesieniu Kodeksu Napoleona bądź w całości, bądź w części” ${ }^{29}$. Sposoby realizacji tego zamierzenia roztrząsano wielokrotnie podczas kolejnych sesji. W tym samym kontekście debatowano również o francuskiej procedurze. Nie wiadomo dlaczego Autor te istotne, jak się wydaje, okoliczności pomija, co sprawia wrażenie, że ściśle poza badaną instytucją nie chce dostrzec innych zagadnień, nieco szerszego tła i przynajmniej w części odsłonić go czytelnikowi. Problemy te były przecież przedmiotem zainteresowania nauki. Zwięzłe wyjaśnienie ze wskazaniem na literaturę przedmiotu byłoby tu bardzo na miejscu.

${ }^{26}$ Sz. Askenazy, Zagrożenie Kodeksu Napoleona przy utworzeniu Królestwa Polskiego, „Gazeta Sądowa Warszawska” 28.05.1908 r., s. 333 (r. XXXVI, nr 22).

${ }^{27}$ Note du Prince Adam Czartoryski présentée a l'Empereur Alexandre I a Chaumont en 1814. Chaumont, 7/19 mars 1814. Rkps B. Czart. 5239, k. 209, 221.

${ }^{28}$ Rkps. B. Czart. 5233, k. 5 i n.

${ }^{29}$ Ibidem, k. 8 i n. 
Warto postawić jeszcze jedną kwestię. Otóż wydaje się, że w ówczesnej sytuacji nie było najważniejsze to, że koła konserwatywne posiadające swą reprezentację w Komitecie Reformy znalazły warunki dogodne do tego, aby „o zniesieniu rozwodów można było myśleć", ale to, co o tej sprawie mniemał Aleksander I. Car natomiast (i jego otoczenie!) był zmuszony rozważyć poważne racje natury czysto politycznej, przed którymi wszelkie względy związane z dotychczasowym porządkiem prawnym w Księstwie, jurydycznymi koncepcjami polityków czy uczonych, a tym bardziej wyobrażeniami tego czy innego prawnika musiały ustąpić. Rozstrzygnięcie zależało więc od woli Aleksandra, a nie od intencji czy prac zwolenników lub przeciwników rozwodów oraz ich opinii o zaletach reklamowanych przez nich rozwiązań. Car w maju 1814 roku kazał kodeks znieść, a niemal dokładnie rok później zdecydował o zachowaniu w mocy obowiązujących praw cywilnych i kryminalnych do czasu, aż nie zostaną wprowadzone w życie nowe kodyfikacje, których opracowanie zalecił, o czym przesadzały podpisane przez monarchę 13/25 maja 1815 roku „Zasady Konstytucji Królestwa Polskiego” (art. 8). Tekst tego doniosłego aktu, który odczytano podczas 91 sesji Komitetu Reformy w dniu 15 czerwca 1815 r., wywołał wśród obecnych wielkie poruszenie i jak zaznacza protokół: „radości i wdzięczności uczucia”30. Zagrożony pierwotnie kodeks cywilny ostatecznie przetrwał, choć w zmienionej postaci. Przesądziło o tym jednak carskie: byt' po siemu! A gdzieś w cieniu, za kulisami pozostawały usilne prace Nowosilcowa, któremu, jak pisał Henryk Grynwaser, „kodeks był potrzebny jako składowa część tego muru, który zaczął wznosić pomiędzy Litwą a Królestwem"31.

Pięć kolejnych rozdziałów książki Piotra Pomianowskiego tworzy obszerny opis przebiegu procesu rozwodowego. Na nich spoczywa punkt ciężkości pracy. I tak w rozdziale II - Podmioty procesu rozwodowego (s. 71-100) Autor przedstawił uczestników postępowania. Obiektem jego zainteresowania był najpierw sąd rozwodowy, potem kolejno prokurator, huissier, pisarz wraz z podpisarzem. Rozpatrzył następnie Autor pozycję prawną stron, a dalej zajął się ich pełnomocnikami. Sporo miejsca poświęcił urzędnikom stanu cywilnego. W najobszerniejszym w książce rozdziale III zatytułowanym Przebieg procesu rozwodowego (s. 101-165) Autor ze znajomością rzeczy objaśnił w świetle Kodeksu Napoleona (oraz kodeksu procedury) skomplikowane materie procesu rozwodowego z przyczyny oznaczonej (z jego licznymi stadiami) oraz procesu rozwodowego z wzajemnego zezwolenia, aby następnie przejść do omówienia czynności bez-

30 Ibidem, k. 516.

${ }^{31}$ H. Grynwaser, Kodeks Napoleona w Polsce, t. I: Księstwo Warszawskie, Warszawa 1915, s. 55 i n. (osobna odbitka z „Themis Polskiej”), s. 65 i n.; idem, Kodeks Napoleona w Polsce, [w:] tegoż, Pisma, t. I, Wrocław 1951, s. 78 i n. 
pośrednio poprzedzających wydanie wyroku, dalej wyroków, rodzajów wyroków stanowczych, spraw, które nie zostały zakończone wyrokiem, i wreszcie zakończyć na postępowaniu apelacyjnym i kasacyjnym. W noszącym tytuł Podstawy wyroków rozwodowych rozdziale IV (s. 167-209) wyjaśnił Autor specyfikę orzeczenia rozwodu ze względu na gwałty, srogości i ciężkie obelgi (osobno na tej samej podstawie po okresie doświadczenia), zaraz dalej z powodu cudzołóstwa ${ }^{32}$, skazania współmałżonka na karę hańbiącą oraz ze względu na wcześniejszą separację. Rozdział zakończył krótkim porównaniem orzecznictwa polskiego i francuskiego z punktu widzenia podstaw wyroków rozwodowych. W rozdziale V zatytułowanym Rozstrzygnięcia dodatkowe (s. 211-229) Autor rozpatrzył kwestie związane z orzeczeniem o winie, opieką nad dziećmi, sprawami majątkowymi, alimentami, karami za cudzołóstwo, kosztami procesu. Zwięzły rozdział VI (s. 231-238) traktuje o istotnej czynności ogłoszenia wyroku (Ogłoszenie wyroku rozwodowego przez urzędnika stanu cywilnego).

Po analizie przebiegu procesu rozwodowego Piotr Pomianowski podjął próbę określenia skali zjawiska rozwodów, czemu poświęcił rozdział VII (Skala zjawiska, s. 239-257). Z przedstawionych zestawień wynika, że Autor ustalił i źródłowo potwierdził ponad 900 rozwodów orzeczonych przez właściwe sądy w Bydgoszczy, Kaliszu, Kielcach, Krakowie, Lublinie, Łomży, Płocku, Poznaniu, Radomiu, Siedlcach, Suwałkach, Warszawie ${ }^{33}$. Przyznał jednocześnie, że „oszacowanie ich ogólnej liczby jest trudne ze względu na szczątkowy charakter zachowanych źródeł". Wskazał, że ,względnie pełne dane dotyczące większego terytorium zachowały się jedynie dla departamentu, a następnie województwa kaliskiego". W związku z tym, po uczynieniu pewnych zastrzeżeń uznał Autor, że: „liczba 164 wyroków rozwodowych kaliskiego trybunału mniej więcej odpowiada rzeczywistej liczbie rozwodów ogłoszonych w departamencie, a następnie województwie kaliskim”. Mimo tych ograniczeń Autor podjął jednak próbę „oszacowania liczby rozwodów ogłoszonych na ziemiach polskich na podstawie Kodeksu Napoleona" i postanowił posłużyć się do tego celu ,jedynie danymi z Warszawy, Krakowa i Kaliskiego”. Po licznych zastrzeżeniach (,załóżmy”, ,przyjmijmy”, „uznajmy”, ,pomińmy”) 34 i przeprowadzeniu „stosownych obliczeń” Autor doszedł , do przekonania, że w sumie na ziemiach polskich na podstawie Kodeksu Napoleona ogłoszono niespełna 2000 rozwodów, czyli jeden rozwód przypadał na 35000-40000 mieszkańców”. Wynik ten,

${ }^{32}$ Dość osobliwa, właściwa bardziej opracowaniom innego niż historycznoprawne charakteru, jest konstatacja Autora: „Zatem przeprowadzone badanie potwierdza stereotyp, że kobieta częściej zdradza z pobudek emocjonalnych i mocniej angażuje się psychicznie w romans, a mężczyzna - ze względu na popęd seksualny" (s. 206).

${ }_{33}$ Przedstawił je Autor także w obszernym aneksie (s. 329-442).

${ }^{34}$ Nie jest jasne, dlaczego za Autorem czytelnik ma u z n a ć, że Kraków wraz z okręgiem przed 1816 rokiem liczył 88 tys. mieszkańców, a po tym roku już 146 tys. (s. 251). 
zdaniem Autora, oznacza, że ,polskie sądy orzekały rozwody nieco częściej niż ich odpowiedniki działające we Francji” (s. 248 i n.).

Ostatni - VIII rozdział monografii (Charakterystyka rozwodzacej się populacji, s. 259-285) ma już całkiem inną specyfikę. Jest swego rodzaju historyczno-socjologicznym szkicem, za pomocą którego Autor próbował odmalować zbiorowy portret kilkuset rozwodzących się par znanych mu z materiałów źródłowych. Charakterystykę tej populacji wykreślił biorąc pod uwagę szereg zmiennych, a mianowicie to, kto był inicjatorem rozwodu, jaki był wiek rozwodników, jak długo trwało małżeństwo. Autor nie pominął także wyznania i zawodu małżonków, ich miejsca zamieszkania, umiejętności złożenia podpisu, przypisywanych im predykatów.

Zestawienie wykorzystanych przez Autora źródeł i dość obszernej przecież literatury wykazuje pewne luki. Piotr Pomianowski wyraźnie stwierdził, że „tematem książki jest praktyka stosowania Kodeksu Napoleona, a nie prace legislacyjne nad wprowadzonymi w nim zmianami” (s. 66). Oczywiście nie sposób kwestionować tego założenia. Trzeba stwierdzić jasno, że prace nad zmianami w kodeksie cywilnym w dobie Królestwa Polskiego można uznać za zupełnie odrębne, a do tego trudne i obszerne zagadnienie. Czy jednak przez nadto rygorystyczną realizację wspomnianego założenia Autor nie pozbawił się pewnych możliwości, instrumentów, które leżały w zasięgu ręki? Wszak dyskusja sejmowa nad projektem prawa o małżeństwie i rozłączeniu toczona w Sejmie w kwietniu 1818 roku zawiera odniesienia do wcześniejszej praktyki. Parlamentarzyści wskazywali na konkretne doświadczenia związane z funkcjonowaniem prawa francuskiego w polskich warunkach. Sądzę, że przydałby się Autorowi zapis tej dyskusji utrwalony w szczegółowym diariuszu sejmowym ${ }^{35}$. Przykładowo - Dominik Krysiński, deputowany z miasta stołecznego Warszawy (z cyrkułu V), mówił w związku z projektem wniesionym przez Radę Stanu, że ta

wiedziała, że prawowierni Polacy po zaprowadzeniu Kodeksu, chociaż władza cywilna zupełnie zakończyła rozwód i dozwalała bezwarunkowo rozwiedzionym w nowe wchodzić małżeństwa związki, każdy jednak rozwiedziony, nim do powtórnego przystępował małżeństwa, czystej religii przejęty uczuciem, szedł do ołtarza i węzeł małżeński wtenczas miał za rozwiązany, gdy mu go ręka rozwiązała Kościoła ${ }^{36}$.

${ }^{35}$ Diariusz Sejmu Królestwa Polskiego 1818, Warszawa (zob. np. s. 87 i n., 140 i n. w cytowanym druku).

${ }_{36}$ Ibidem, s. 152. Wydaje się, że pewien walor miałaby nawet dyskusja sejmowa z roku 1830. Zob. list Joachima Lelewela do hrabiego Tytusa Działyńskiego z Warszawy datowany na 30 czerwca 1830 roku, zawierający niezwykle plastyczny opis obrad sejmowych, podczas których roztrząsano „projekta o rozwodzie” oraz „przemawiano głośno, aby wrócić do kodeksu francuskiego”. Zob. Korespondencja Joachima Lelewela z Tytusem hr. Działyńskim, wyd. Z. Celichowski, Poznań 1884, s. $45-52$. 
Fragment ten dotyczy, jak sądzę, problemu, którym Autor zajmuje się w zakończeniu swej książki (s. 288 i n.).

Ponadto dziwi fakt, że Autor nie sięgnął w ogóle do literatury pamiętnikarskiej. Szkoda, bo wydaje się, że mogła być ona z powodzeniem spożytkowana i to na różne sposoby. Wszak snując rozważania nad cudzołóstwem jako podstawą do orzeczenia rozwodu, Autor sam zaznaczył, że

zachowane fragmentarycznie akta sądowe zawierają multum informacji o prozie życia cudzołożników wywodzących się z kręgów rzemieślników, włościan czy ziemiaństwa. Przedstawiciele sfer wyższych, których romanse były niejednokrotnie obiektem zainteresowania opinii publicznej i pamiętnikarzy, w procesach sądowych już tak wylewni nie byli (s. 206).

Jeśli tak, to tym bardziej trzeba było sięgnąć po pamiętniki i poszukać w nich nie tyle „informacji o prozie życia”, ale wszelkich szczegółów dotyczących rozwodowych perypetii i sądowego finału głośniejszych skandali małżeńskich wstrząsających opinią publiczną. Może znalazłyby się ciekawe oceny ujmujące nie tylko moralno-obyczajową stronę sprawy, ale także jej wymiar prawny. Bez wątpienia relacje pamiętnikarskie mogły odegrać istotną rolę na innej jeszcze płaszczyźnie. W ich świetle wyraźniej jawiłby się problem bezpośrednich przyczyn, ale i głębszego podglebia oporu duchowieństwa oraz kół konserwatywnych wobec prawa francuskiego, zwłaszcza małżeńskiego, w dobie Księstwa Warszawskiego oraz Królestwa Polskiego. Szkoda zatem, że Autor nie wykorzystał pamiętników tak znaczących w kontekście jego zainteresowań osobistości, jak Feliks Łubieński ${ }^{37}$ czy Kajetan Koźmian ${ }^{38}$. Jestem przekonany, że warto było sięgnąć do wspomnień Eustachego Antoniego Iwanowskiego, który stosunkom rządu Księstwa Warszawskiego z Kościołem Katolickim (a tu także napięciom związanym z wprowadzeniem Kodeksu Napoleona, kwestiami natury finansowej i in.) poświęcił kilkadziesiąt stron ${ }^{39}$.

$\mathrm{Na}$ tle tej generalnej kwestii nasuwa się jeszcze jedna uwaga. Otóż o obstrukcyjnej postawie kleru wobec urządzeń francuskich w Księstwie Warszawskim Autor wspomina wielokrotnie. Odnoszę jednak wrażenie, że motyw ten bezwzględnie dominuje, natomiast zabrakło w pracy wskazania, że walka duchowieństwa z francuskimi nowinkami to jednak tylko część szerszego zjawiska. Rzecz w tym, że ten front nie był utrzymywany jedynie siłami duchownych. W Księstwie dość powszechnie atakowano przecież wiele wprowadzonych tam na wzór francuski urządzeń - ustrojowych, prawnych, administracyjnych, wojskowych, a także ko-

${ }^{37}$ Pamiętnik hr. Feliksa Łubieńskiego ministra sprawiedliwości, skreślił i opracował W. Chomętowski, Warszawa 1890.

${ }^{38}$ K. Koźmian, Pamiętniki, t. I-III, wstęp, komentarze J. Willaume, Wrocław 1972.

39 Wspomnienia lat minionych (zob. s. 43 i n.). 
jarzonych z nimi ludzi. Co więcej, fala krytyki stale narastała, ale jej animatorem, także w kwestii rozwodów, nie był przecież tylko kler. Jak pisał Maciej Loret:

Nadana Księstwu w duchu na wskroś nowożytnym konstytucja, zastąpienie dotychczasowych norm i urządzeń prawnych kodeksem Napoleona - stworzyły przed narodem nowe, nieznane mu dotychczas drogi życia społecznego. Zbyt nagłe i zbyt forsowne zastosowanie tak doniosłych przemian nie mogło się obejść bez zgrzytu, tym bardziej, że społeczeństwo zostało nimi zaskoczone i nie od razu mogło się z nimi zżyć i oswoić; niektóre z nich raziły, inne wprost godziły w utarte tradycją i zwyczajami pojęcia. Rozdźwięk ten najjaskrawiej wystąpił atoli teraz w dziedzinie kościelnej.

\section{Zaraz dalej badacz kontynuował myśl w następujący sposób:}

Postanowienia kodeksu Napoleona w sprawach małżeńskich i rozwodowych, kwalifikujące małżeństwo jako umowę czysto cywilną, mogły być chwalone tylko w małej, przesiąkniętej francuszczyzną części społeczeństwa; w szerokich warstwach ludności wywoływały natomiast niezadowolenie, a już zgoła spotykały się z silnym, niemilknącym protestem pośród duchowieństwa ${ }^{40}$.

Halina Bachulska zwracała natomiast uwagę, że społeczeństwo polskie, które z jednej strony z entuzjazmem odnosiło się do Napoleona i jego czynów

było $\mathrm{w}$ istocie swej konserwatywne i z powątpiewaniem, a potem z nieufnością odnosiło się do zmian, zaprowadzonych w Księstwie, pod wpływem liberalizmu, wiejącego z Zachodu. Przywiązane do tradycji każdą nowość witało z niechęcią, obawiało się zmiany. Ten moment psychologiczny szczególnie silnie zarysował się wśród jednej z warstw społecznych, wśród duchowieństwa katolickiego, które siłą rzeczy stanęło w opozycji wobec zmian wniesionych przez kodeks francuski i które prowadziło ciągłą walkę z rządem Księstwa Warszawskiego.

\section{W innym miejscu autorka dodawała:}

Nie wchodząc w meritum sprawy zaznaczyć tylko muszę, że konserwatyzm i obskurantyzm ówczesnego społeczeństwa polskiego tworzył głuchą opozycję przeciwko kodeksowi francuskiemu i ludziom, którzy byli jego wykonawcami na terenie Księstwa ${ }^{41}$.

${ }^{40}$ M. Loret, Stosunek Kościoła do państwa w Księstwie Warszawskim, „Przegląd Narodowy” 1914, r. VII, t. XIII, nr 2, s. 130 i n. Na marginesie warto wskazać na ciekawy wątek poruszony przez Loreta, do którego brak odniesień w opracowaniu Piotra Pomianowskiego. Loret pisał mianowicie: „Nowe prawodawstwo krajowe podzieliło ius maiestaticum circa sacra między dwie władze - ministerium spraw wewnętrznych i religii oraz ministerium sprawiedliwości, któremu podlegał tzw. wydział sądowy tolerancji, wchodzący w skład sądów apelacyjnych. Do ministerium spraw wewnętrznych i religii należały stosunki duchowieństwa z rządem, polityczne i administracyjne; do wydziału tolerancji w ministerium sprawiedliwości należało rozpoznawanie wypadków, które naruszały tolerancję religijną, oraz baczenie, aby sądy kościelne nie przywłaszczały sobie atrybucji, służących władzy cywilnej. Wydział tolerancji był nadto wyższą instancją w sprawach małżeńskich rozwodowych oraz dotyczących naruszenia majątku kościelnego". Ibidem, s. 131.

${ }^{41}$ H. Bachulska, Księstwo Warszawskie w oświetleniu satyry politycznej, s. 18 i n. 
Wskażmy wreszcie, że nie uprawiano jedynie „głuchej opozycji”, skoro na sejmie w 1811 roku otwarcie krytykowano Kodeks Napoleona, a - jak pisał Jan Jakub Litauer - „poseł gostyński p. Ciechomski już bez żadnych obsłonek odważył się przemówić wprost za dawnym prawem polskim i przeciw Kodeksowi Napoleona". Ten sam autor, przywołując opinię znanego historyka wyprowadził wniosek, że:

Nie ulega więc wątpliwości, że znaczna część społeczeństwa na razie znalazła się w opozycji przeciw Kodeksowi francuskiemu, którym - jak stwierdza to Skarbek - dotknięte zostały uczucia religijne i rodzinne oraz dotychczasowe przyzwyczajenia w sferze stosunków majątkowych ${ }^{42}$.

Już po utworzeniu Królestwa w toku prac nad reformą prawa cywilnego kodeks krytykowała otwarcie także część palestry. Konserwatyści, którzy już dawniej byli mu niechętni, stanęli natomiast wobec pewnego dylematu, a mianowicie: jak pogodzić swój sprzeciw wobec francuskiego prawa małżeńskiego z posłuszeństwem wobec rządu, który wysuwał teraz propozycje modyfikacji Kodeksu Napoleona, a nie jego zniesienia. Piotr Pomianowski nie wskazał na te aspekty. Nie uwzględnił też wymienionych publikacji Loreta, Bachulskiej i Litauera.

Wydaje się, że dość dotkliwym brakiem jest, o czym już zresztą wspomniano, pominięcie cennej pracy Ignacego Daniłowicza z 1818 roku zatytułowanej Kodeks Napoleona w porównaniu z prawami polskimi i litewskimi. W piśmiennictwie niejednokrotnie zwracano na nią uwagę ${ }^{43}$. Na kartach tej rozprawy Daniłowicz z właściwym sobie znawstwem, naukowym zacięciem i polotem poddał analizie porównawczej instytucje prawa francuskiego oraz polskiego i litewskiego, uwzględniając oczywiście także problematykę małżeństwa i rozwodów ${ }^{44}$. Ponadto badacz podjął refleksję nad problemem recepcji praw francuskich w Polsce i dał ich ogólną charakterystykę. Wydaje się, że warto korzystać z opinii Daniłowicza, historyka i prawnika, którego jeszcze w czasach jego pracy naukowej w Wilnie uważano za bardzo obiecującego uczonego, a później nawet za osobistość wybitną. Wspomniane dzieło Daniłowicza jest tym cenniejsze, że w uwagi krytyczne

42 J.J. Litauer, Przeciwnicy Kodeksu, „Gazeta Sądowa Warszawska” 28.05 .1908 r., s. 366 (r. XXXVI, nr 22).

${ }^{43}$ Zob. np. A. Janulaitis, Ignas Danilavičius, Lietuvos ir jos teisès istorikas, Kaunas 1932, s. 664 i n., 675 i n., 727 i n.; J. Bardach, Statuty litewskie a prawo rzymskie, Warszawa 1999, s. 99 i n.; H. Beresnevičiūtè-Nosálová, Lojalumu krizè: Lietuvos bajoru politinès sąmonès transformacija 1795-1831 m., Vilnius 2001, s. 104 i n.; W. Witkowski, Kodeks Napoleona w ocenie wileńskiego prawnika Ignacego Daniłowicza z 1818 r., [w:] Państwo, prawo, społeczeństwo $w$ dziejach Europy środkowej. Księga Jubileuszowa dedykowana Profesorowi Józefowi Ciagwie w siedemdziesięciolecie urodzin, Katowice, Kraków 2009, s. 819-826; S. Godek, III Statut litewski w dobie porozbiorowej, Warszawa 2012, s. 88 i n.

${ }^{44}$ I. Daniłowicz, Kodeks Napoleona, s. 51, 65 i n., 72 i n., 105 i n., 118 i n., 153 i n., 167, 171. 
zaopatrzył je książę Adam Jerzy Czartoryski. Uwzględnione w druku przypiski recenzenta są ciekawym świadectwem stosunku księcia do prawa francuskiego i generalnie do recepcji praw obcych. W ocenach Czartoryskiego pobrzmiewa wyraźnie argumentacja polityczna.

Na marginesie pragnę zwrócić uwagę na pewien szczegół, właściwie nieznany, ale interesujący i może nie bez znaczenia dla refleksji nad stosunkiem Daniłowicza do prawa francuskiego, a szerzej nad dyskusją o przyszłości Kodeksu Napoleona w Polsce po upadku Księstwa Warszawskiego. Otóż ciekawe czy na poglądach Daniłowicza zaważyły w jakiejś mierze jego kontakty z Janem Wincentym Bandtkie ${ }^{45}$ podczas pobytu wileńskiego uczonego w Warszawie w 1817 roku? Ten ostatni był, jak wiadomo, szczerym zwolennikiem i wytrwałym obrońcą praw francuskich w Polsce mocno zaangażowanym w publicznej dyskusji na temat ich przyszłości w Królestwie Polskim.

Nie dotarł Autor do obszernej pracy M.P. Sołowiowa, O niedziejstwitielnosti braka i razwodzie po zakonam Carstwa Polskago, „Juridiczeskij Wiestnik” 1873 (janwar, s. 36-82; fewral, s. 17-42; mart/apriel, s. 7-50; maj/ijun, s. 16-56; ijul/ awgust, s. 3-43). Sądzę, że na uwzględnienie zasługiwał jubileuszowy, poświęcony setnej rocznicy wprowadzenia Kodeksu Napoleona, numer „Gazety Sądowej Warszawskiej" z 28 maja 1908 roku z tekstami Karola Dunina, Aleksandra Kraushara, Szymona Askenazego, Feliksa Ochimowskiego, Jana Mrozowskiego, Marka Kuratowa, Szymona Rundsteina, Stanisława Posnera i Jana Jakuba Litauera. Szkoda, że Autor nie wykorzystał gruntownego i klasycznego już opracowania Józefa Bielińskiego, Królewski Uniwersytet Warszawski (1816-1831), t. II, Warszawa 1911, w którym znalazłby sporo wzmianek na temat Kodeksu Napoleona jako przedmiotu wykładu w Warszawie (mógłby je z powodzeniem spożytkować m.in. w wywodach snutych na s. 71 i n., przypis 2), obiektu zainteresowań naukowych czy wystąpień publicystycznych.

Pominął Autor także książkę Stanisława Tylbora, Próby reformy kodeksu cywilnego polskiego (1834-1854), Warszawa 1927, szkic Eugeniusza Waśkowskiego, Rozwój ustawodawstwa cywilnego w XIX wieku, Wilno 1925 (osobna odbitka z „Rocznika Prawniczego Wileńskiego” 1925, ss. 28), rozprawę Jana Kamińskiego, Prawo francuskie w Polsce, „Pamiętnik Historyczno-Prawny” 1931, t. X, z. 3 , s. 217-287, obszerne opracowanie Marii Manteufflowej, J.K. Szaniawski. Ideologia i działalność 1815-1830, Warszawa 1936, artykuł Władysława Sobocińskiego, Rozwój ustawodawstwa cywilnego w Królestwie Polskim i w Rosji do rosyj-

${ }^{45}$ Najbolieje wydajuszczijesja stuczai wo wriemja putieszestwija iz Wilny w Awstriju i Italiju s 1817 po 1820 g., zapisannyje dlja pamjati Brestskim kafedralnym kanonikom ks. Michajłom Bobrowskim, [w:] Opisanije rukopisnago otdzielenija Wilenskoj Publicznoj Biblioteki, wyp. 5, Wilna 1906, s. 67. 
skiej reformy sadowej. (Zarys historyczno-porównawczy), „Annales Universitatis Mariae Curie-Skłodowska, sectio G” 1965, 12.4, s. 113-178 oraz tekst Leonida Gorizontowa, Ustawodawstwo dotyczace matżeństw różnowierczych $w$ historii stosunków rosyjsko-polskich, „Przegląd Wschodni” 2000, 7.1, s. 69-95. Nie wykorzystał wreszcie Piotr Pomianowski spostrzeżeń Agnieszki Witczak poczynionych w książce zatytułowanej Działalność konsystorza pomorskiego i gdańskiego w sprawach malzeńskich w latach 1733-1734, Gdańsk 2007.

Wypada jeszcze zwrócić uwagę na drobniejsze uchybienia. Wydaje się, że Autor starał się podawać tytuły oraz cytaty ze źródeł lub dawniej wydanych opracowań z zachowaniem ówczesnej pisowni. Nie był w tym jednak konsekwentny. Autor kilka razy przywoływał drugi tom poznańskiej edycji Dzieł Tadeusza Czackiego z 1844 roku $^{46}$, odsyłając czytelnika do konkretnych stron i przypisów tej pozycji (s. 13, 58, 59, 135). Zastosowane rozwiązanie sprawia jednak, że czytelnik nie wie, które dzieło Czackiego Autor cytuje. Autor korzystał oczywiście z fundamentalnego opracowania zatytułowanego O litewskich i polskich prawach. Podobną, a z punktu widzenia komfortu czytelnika, wątpliwą metodę zastosował Autor także powołując się na Studia galicyjskie Stanisława Grodziskiego ${ }^{47}$ (s. 35, 37, 63). W istocie cytował szkic Grodziskiego zatytułowany Źródta prawa $w$ Galicji w latach $1772-1848$ pomieszczony w tym obszernym zbiorze ${ }^{48}$. Autor niepotrzebnie do znudzenia powtarzał w rozwiniętej formie niektóre tytuły cytowanych prac. Przykładowo rozprawa Bronisława Fidelusa na temat rozwodów w orzecznictwie sądów Wolnego Miasta Krakowa przywołana jest w przypisie 6 (s. 15), potem zaraz w tejże pełnej postaci w 7 (s. 16) i ponownie w 16 (s. 18), a to wszystko w ramach tej samej części pracy (wprowadzenia). Następnie publikacja ta jest jeszcze wielokrotnie cytowana $\mathrm{w}$ rozwiniętej formie w kolejnych rozdziałach książki (np. przypis 21, s. 76; przypis 11, s. 171; przypis 11, s. 241). Podobnie artykuł Marzeny Dyjakowskiej na temat rejestracji stanu cywilnego w Księstwie Warszawskim i w Królestwie Polskim został zacytowany w przypisie 77 na s. 89 i zaraz znów w takiej samej rozwiniętej postaci w przypisie 84 na s. 91 w obrębie tego samego rozdziału. To samo uczynił Autor z książką Wojciecha Witkowskiego o Komisji Rządowej Sprawiedliwości (przypisy 6 i 27 na s. 241 i 243 w rozdziale 7). Przykładów takich można podać więcej. Najwyraźniej intencją Autora było stosowanie formy rozwiniętej przy każdym pierwszym cytowaniu danej pozycji w kolejnych częściach rozprawy, ale założenia tego nie wypełniał konsekwentnie. Powtórzenia w ocenianej monografii pojawiają się zresztą także

${ }^{46}$ Dzieła Tadeusza Czackiego zebrane w 3ch tomach i wydane przez hr. Edwarda Raczyńskiego, t. II, Poznań 1844.

${ }^{47}$ S. Grodziski, Studia galicyjskie. Rozprawy i przyczynki do historii ustroju Galicji, red. i słowo o autorze G. Nieć, Kraków 2007.

${ }^{48}$ Ibidem, s. 11-22. 
w innych formach. Nota o piśmie Feliksa Łubieńskiego umieszczona w przypisie 143 na s. 63 jest identyczna, jak ta w przypisie 2 na s. 287. Ponadto w przypisach, w których wymieniono większą liczbę publikacji układ cytowanych pozycji jest dość dowolny (np. s. 17, przypis 13; s. 163, przypis 260).

Bez wątpienia badania Piotra Pomianowskiego pozwoliły na sfalsyfikowanie powtarzanej od dziesięcioleci w piśmiennictwie naukowym opinii o znikomej liczbie kilku lub najwyżej kilkunastu rozwodów orzeczonych w dobie istnienia Księstwa Warszawskiego oraz Królestwa Polskiego. Znacznie większą zasługą Autora jest umiejętne odsłonięcie fragmentu praktyki sądowej i otwarcie drogi do dalszych badań w tym kierunku. Ważne są wnioski Autora, iż pomimo dość licznych odrębności, które dało się zaobserwować w polskiej praktyce sądowej, a które Autor szczegółowo opisał, zasadniczo „recepcja prawa rodzinnego przebiegła sprawnie" (s. 299 i n.). 